\title{
Decontamination of instruments and control of cross infection in general practice
}

\author{
D R Morgan, T J Lamont, J D Dawson, Christopher Booth
}

TABLE I-Decontamination system used in general practices

\begin{tabular}{lc}
\hline System & $\begin{array}{c}\text { No of } \\
\text { practices } \\
(\mathrm{n}=382)\end{array}$ \\
\hline Autoclaves & 186 \\
Hot water disinfectors & 84 \\
Hot air ovens & 56 \\
Chemical disinfectants & 41 \\
Central sterile supply & 13 \\
$\quad$ departments & 2 \\
None & \\
\hline ॠIncluding 10 domestic type
\end{tabular}

pressure cookers.
Professional and Scientific Division, British Medical Association, London WC1H 9JP

D R Morgan, MPHIL, assistant head of division

$\mathrm{T} \mathrm{J}$ Lamont, BA, projects and research officer

$\mathrm{J}$ D Dawson, $\mathrm{MB}$, head of division

Sir Christopher Booth, MD, chairman, board of science and education

Correspondence to:

Mr Morgan.

Br Med F 1990;300:1379-80

\section{Abstract}

Objective-To assess the effectiveness of decontamination procedures in general practice.

Design-Anonymous postal questionnaire survey of 600 general practitioners randomly selected from the national register.

Setting-General practices throughout the United Kingdom.

Subjects -382 General practitioners, a response rate of $65 \%$.

Results - 186 General practitioners had autoclaves but 125 used hot water disinfectors or chemical disinfectants to reprocess instruments. $22 \%$ (474/2132) Of high risk instruments were inadequately decontaminated. Decontamination was performed by the practice nurse or receptionist in 306 practices. Knowledge of treatment of spillages of blood fluids was uncertain, and only 114 general practitioners used effective methods for dealing with spillages.

Conclusions-A comprehensive central code of practice for control of infection is needed for primary health care staff.

\section{Introduction}

In the United Kingdom general practitioners and their staff provide comprehensive primary health care services for roughly 55 million people. On average patients visit their general practitioner three times a year; this is equivalent to 750000 patient consultations a day. As a result of changes in the organisation of primary health care services the number of minor operations and screening procedures performed by general practitioners may increase. Appropriate decontamination of surgical instruments and effective infection control policies will be essential.

The need for rigorous decontamination procedures is increased by the rising numbers of people infected with HIV; there is also a risk of cross infection with hepatitis B, tuberculosis, cytomegalovirus, and human papillomavirus. In addition, general practitioners have new responsibilities for staff under the Control of Substances Hazardous to Health Act 1989, which obliges them, as employers, to assess the risks to health in the workplace.

Although small studies of decontamination methods in general practice have been undertaken, ${ }^{1-3}$ no national survey of practices has been conducted.

\section{Methods}

A computer generated random sample of 600 general practitioners was extracted from a national database of 36098 general practitioners holding registrable qualifications in the United Kingdom in April 1989. These doctors were sent an unidentifiable, single sided questionnaire on 3 May 1989 with a reply paid envelope. After four weeks all 600 general practitioners were sent a reminder card giving a telephone number at

\section{Risk category of instruments used in general practice}

High Instruments that penetrate the skin, enter
normally sterile body areas, or come into
contact with severely ulcerated mucous
membranes

the BMA in case a further copy of the questionnaire was needed.

The questionnaire consisted of 10 questions, seven of which covered working practices in general practice surgeries. The questions concerned the type of decontamination system used; the equipment available in branch surgeries, when applicable; the person chiefly responsible for reprocessing used instruments; and the method of treating different instruments. The relative risks of procedures to patients were assessed (see box) with reference to the BMA's code of practice for sterilisation of instruments and control of cross infection. ${ }^{+}$Open questions were asked about the use of chemical disinfectants and the treatment of spillages of body fluids. Three additional questions concerned the type of area served by the practice, the number of patients registered with the practice, and the number and category of practice staff. Proportions were compared by $\chi^{2}$ tests.

\section{Results}

We received 382 completed questionnaires, a response rate of $65 \%$. Ten questionnaires were invalidated because, for example, the doctor had moved or retired from the practice. For each question invalid answers were discounted before the data were analysed.

Table I shows the main decontamination systems used by respondents. Almost half of the respondents had an autoclave. We had expected that having an autoclave would be associated with several variables, but no significant association was found between having an autoclave and size of practice, number of partners, or setting of practice (urban or rural) (table II).

Of the 382 general practitioners, 131 worked

TABLE II-Distribution of variables thought likely to be associated with ownership of autoclaves

\begin{tabular}{lcc}
\hline Type of practice with autoclave & $\%($ No) of practices & p Value \\
\hline Singlehanded practice & $44(11 / 25)$ & \\
Group practice & $49(175 / 357)$ & 0.63 \\
Practice with <5500 patients & $45(64 / 142)$ & \\
Practice with $\geqslant 5500$ patients & $48(114 / 240)$ & 0.65 \\
Practice in rural area & $40(20 / 50)$ & 0.25 \\
Practice in urban area & $50(60 / 121)$ & \\
\hline
\end{tabular}


TABLE III - Method used to provide sterile instruments

\begin{tabular}{|c|c|c|c|c|c|c|}
\hline Instrument & Autoclave & $\begin{array}{c}\text { Hot air } \\
\text { oven }\end{array}$ & $\begin{array}{l}\text { Central } \\
\text { sterile } \\
\text { supply } \\
\text { department }\end{array}$ & Single use & Boiling & $\begin{array}{l}\text { Chemical } \\
\text { disinfectants }\end{array}$ \\
\hline Vaginal speculum $(n=381)$ & 173 & 56 & 13 & 24 & 88 & 26 \\
\hline Surgical scissors $(n=377)$ & 172 & 61 & 15 & 7 & 77 & 39 \\
\hline Forceps $(n=367)$ & 170 & 61 & 16 & 10 & 74 & 32 \\
\hline Scalpels $(\mathrm{n}=337)$ & 99 & 30 & 9 & 168 & 30 & 10 \\
\hline Stitch cutters $(n=354)$ & 63 & 16 & 7 & 237 & 19 & 11 \\
\hline \multirow{2}{*}{$\begin{array}{l}\text { Sets for inserting intrauterine } \\
\text { contraceptive devices }(n=316)\end{array}$} & & & & & & \\
\hline & 147 & 49 & 31 & 27 & 48 & 8 \\
\hline
\end{tabular}

TABLE IV - Recommended and inadequate methods of decontamination and number (percentage) of practices using inadequate methods

\begin{tabular}{|c|c|c|c|}
\hline Instrument & Unacceptable methods & Recommended method & $\begin{array}{l}\text { Practices using } \\
\text { inadequate } \\
\text { decontamination }\end{array}$ \\
\hline $\begin{array}{l}\text { Vaginal speculum }(n=381) \\
\text { Surgical scissors }(n=377) \\
\text { Forceps }(n=367) \\
\text { Scalpel }(n=337) \\
\text { Stitch cutters }(n=354) \\
\text { Sets for inserting intrauterine } \\
\quad \text { contraceptive devices }(n=316)\end{array}$ & $\begin{array}{l}\text { Boiling, chemical disinfectants, } \\
\text { or soap and water }\end{array}$ & $\begin{array}{l}\text { Sterilisation by autoclave, } \\
\text { hot air oven, or central } \\
\text { sterile supply } \\
\text { department }\end{array}$ & $\begin{array}{l}115(31) \\
121(32) \\
110(30) \\
40(12) \\
31(9) \\
57(18)\end{array}$ \\
\hline $\begin{array}{l}\text { Auriscope }(n=372) \\
\text { Proctoscope }(n=244) \\
\text { Laryngeal mirror }(n=58)\end{array}$ & $\begin{array}{l}\text { Chemical disinfectants or soap } \\
\text { and water }\end{array}$ & $\begin{array}{l}\text { Heat treatment (all above, } \\
\text { plus boiling) }\end{array}$ & $\begin{array}{r}213(57) \\
29(11) \\
41(71)\end{array}$ \\
\hline $\begin{array}{l}\text { Thermometer }(n=343) \\
\text { Tonometer }(n=15)\end{array}$ & $\begin{array}{l}\text { Autoclaving, boiling, hot air } \\
\text { ovens, or soap and water }\end{array}$ & $\begin{array}{l}\text { Disinfection (chemical } \\
\text { disinfectants) }\end{array}$ & $\begin{array}{r}95(28) \\
7(47)\end{array}$ \\
\hline
\end{tabular}

TABLE V-Methods of dealing with spillages of body fluids

\begin{tabular}{lr}
\hline Method & $\begin{array}{c}\text { No of } \\
\text { practices }\end{array}$ \\
\hline Satisfactory: & \\
Hypochlorites & 114 \\
Doubtful: & \\
Alcohols & 19 \\
Phenolics & 14 \\
Disinfectant & \\
(unspecified) & 43 \\
Detergent (unspecified) & 36 \\
Don't know & 13 \\
Blank & 51 \\
Unsatisfactory: & \\
Skin disinfectants: & \\
Chlorhexidine & 70 \\
$\quad$ Iodine & 3 \\
Quaternary ammonium & \\
compounds & .13 \\
Glutaraldehyde & 4 \\
None & 2
\end{tabular}

*Use of glutaraldehyde is restricted under Control of Substances Hazardous to Health Act. in practices with branch surgeries. Only 73 branch surgeries had separate decontamination facilities; 47 used some form of heat treatment-autoclaves, hot water disinfectors, or hot air ovens - and 18 used some agent other than heat.

Decontamination was performed by the nurse in 274 practices, the general practitioner in 71 , and the receptionist in 32; five general practitioners did not specify who was responsible for decontamination.

General practitioners in practices with no sterilisation facilities can provide sterile instruments by using the facilities of the central sterile supply department or single use instruments that are sterile. Of the general practitioners surveyed, 275 used some form of single use instrument. Of the high risk instruments designated in our questionnaire stitch cutters were the commonest type of single use instrument: 237 practices used single stitch cutters, 156 scalpels, and 93 proctoscopes. Surprisingly, only 27 used single use speculums and only 15 disposable thermometer sheaths or single use thermometers.

One of the questions attempted to determine how selected instruments were treated. Instruments were chosen from different risk categories, according to the procedure undertaken. The questionnaire listed 11 instruments with a series of options for decontamination ranging from basic decontamination with soap and water to autoclaving (table III). Table IV shows the recommended and unsuitable methods of treatment for instruments in different risk categories and the number of practices performing unacceptable decontamination techniques. Analysis showed that $22 \%(474 / 2132)$ of high risk instruments were inadequately decontaminated. This was largely due to inappropriate use of hot water disinfectors.

An open question elicited information on doctors knowledge and practice of correct treatment for spillages of body fluids. The BMA code recommends a 10000 ppm hypochlorite solution or a granular form of hypochlorite ${ }^{+}$; household gloves should be worn when handling these materials. Varying amounts of detail were provided so the responses were analysed on the generic type of chemical used as this was the common denominator of the answers given (table $\mathrm{V}$ ).

\section{Discussion}

Unlike other pilot surveys our study was not restricted to a single region or locality ${ }^{235}$ and there were no established links with the doctors surveyed. Our response rate of $65 \%$ compares favourably with that of similar postal surveys."

It was reassuring that almost half of the practices had autoclaves (including pressure cooker systems). Two previous reports indicated that only $25 \%^{1}$ and $80 \%^{2}$ of practices had autoclaves, and a recent survey of equipment in general practice in Devon and Cornwall showed tht $38 \%$ of respondents owned autoclaves." Nevertheless, $34 \%$ of practices in our survey still used non-sterilising techniques such as hot water disinfectors or chemical disinfectants.

Over a quarter of speculums, surgical scissors, and forceps were inadequately decontaminated. Not all speculums, however, are used for high risk procedures, and speculums used for vaginal examinations (medium risk) may be decontaminated adequately by boiling. Thus we probably overestimated the number inadequately decontaminated.

Because any body fluid could be contaminated with HIV or hepatitis B virus, dealing with spillages should be an important part of any practice's decontamination policy. Only $2 \%$ of respondents reported using gloves, though this information was not specifically asked for in the questionnaire, and only 30\% used effective agents for treating spillages of body fluids.

Many non-technical or nursing staff are responsible for decontamination procedures in general practice, and comprehensive training of staff is therefore essential. The Control of Substances Hazardous to Health Act 1989 demands that employers review every procedure carried out in the workplace that entails contact with a substance hazardous to health; this includes chemical disinfectants, pathogenic organisms, used sharps, and clinical waste. Both money and time will need to be spent to ensure increased safety in general practice.

We have shown the need for a comprehensive central code of practice in control of infection for primary health care staff facing new challenges posed by the introduction of extensive minor operations and screening procedures into general practice.

We thank Deborah Ridout and Hilary Glanville for help with data input and Mr Douglas Altman, Dr John Chisholm, Dr William Dixon, and Mr Peter Hoffman for comments and suggestions. We also thank all the general practitioners who took part in our survey.

1 Hoffman PN, Cooke EM, Larkin DP, et al. Control of infection in general practice: a survey and recommendation. Br.Med f 1988;297:34-6.

2 Farrow SC, Kaul S, Littlepage BC. Disinfection methods in general practice and health authority clinics: a telephone survey. $7 R$ Coll Gen Pract 1988;38:447-9.

3 Rogers J. Sterilisation in GP surgeries. Nursing Times 1989;85:5-69.

4 British Medical Association. A code of practice for sterilisation of instruments and control of cross infection. London: BMA, 1989.

Bradley $\mathrm{N}$, Watkins $\mathrm{S}$. Survey of equipment in general practice. Br. Med 7 1989:299:435-6.

6 Social and Community Planning Research. Survey methods newsletter: postal surveys. London: SCPR, 1987

(Accepted 24 Apri! 1990) 